This is the peer-reviewed version of the following article:

Veljković, Dušan Ž., 2018. Strong C-H/O interactions between polycyclic aromatic hydrocarbons and water: Influence of aromatic system size. Journal of Molecular Graphics and Modelling. 80, 121-125. https://doi.org/10.1016/i.jmgm.2017.12.014

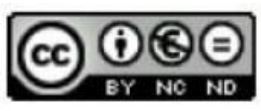

This work is licensed under a Creative Commons - Attribution-Noncommercial-No Derivative Works 3.0 Serbia 
Dušan Ž. Veljković *[a]

Strong $\mathrm{C}-\mathrm{H} / \mathrm{O}$ interactions between polycyclic aromatic hydrocarbons and water: influence of aromatic system size

[a] Dr. D. Ž. Veljković

Department of Chemistry, University of Belgrade

Studentski trg 12-16, Belgrade (Serbia),

E-mail:vdusan@chem.bg.ac.rs

ORCID ID: 0000-0002-1382-8785 


\title{
Strong $\mathrm{C}-\mathrm{H} / \mathrm{O}$ interactions between polycyclic aromatic hydrocarbons and water: influence of aromatic system size
}

\author{
Dušan Ž. Veljković *[a]
}

\begin{abstract}
Energies of $\mathrm{C}-\mathrm{H} / \mathrm{O}$ interactions between water molecule and polycyclic aromatic hydrocarbons with a different number of aromatic rings were calculated using $a b$ initio calculations at MP2/cc-PVTZ level. Results show that an additional aromatic ring in structure of polycyclic aromatic hydrocarbons significantly strengthens $\mathrm{C}-\mathrm{H} / \mathrm{O}$ interactions. Calculated interaction energies in optimized structures of the most stable tetracene/water complex is $-2.27 \mathrm{kcal} / \mathrm{mol}$, anthracene/water is $-2.13 \mathrm{kcal} / \mathrm{mol}$ and naphthalene/water is -1.97 $\mathrm{kcal} / \mathrm{mol}$. These interactions are stronger than $\mathrm{C}-\mathrm{H} / \mathrm{O}$ contacts in benzene/water complex $(-1.44 \mathrm{kcal} / \mathrm{mol})$ while $\mathrm{C}-\mathrm{H} / \mathrm{O}$ contacts in tetracene/water complex are even stronger than $\mathrm{C}$ $\mathrm{H} / \mathrm{O}$ contacts in pyridine/water complexes $(-2.21 \mathrm{kcal} / \mathrm{mol})$. Electrostatic potential maps for different polycyclic aromatic hydrocarbons were calculated and used to explain trends in the energies of interactions.
\end{abstract}

Keywords: polycyclic aromatic hydrocarbons; C-H/O interactions; hydrogen bond; ab initio calculations

\section{Introduction}

Hydrogen bonds are doubtless the most notable and best understood noncovalent interactions in nature [1]. Early models of hydrogen bonding did not recognize the carbon atom as a standard hydrogen bond donor. This was mostly due to relatively low electronegativity of carbon in comparison with the common hydrogen donor atoms like oxygen and nitrogen. However, this concept significantly evolved over recent decades. Many studies have documented that carbon atoms can act as hydrogen donors in weak hydrogen bonds know as $\mathrm{C}-\mathrm{H} / \mathrm{O}$ interactions $[1,2]$. In addition, it was shown that if the hydrogen atom is attached to a polarized carbon atom, it can form hydrogen bonds as strong as those formed by regular hydrogen-donating atoms [3, 4]. Today it is generally accepted that $\mathrm{C}-\mathrm{H} / \mathrm{O}$ interactions represent true hydrogen bonds [5-7] and that they play significant role in the stability of nucleic acid and protein structures, enzymatic activity and crystal packing [8-11]. C-H/O interactions are essential for stabilization of protein structures since it was shown that they make up to $25 \%$ of all hydrogen bonds in the structure of proteins $[12,13]$.

Aromatic molecules represent a special group of $\mathrm{C}-\mathrm{H}$ donors. It is well-known that aromatic molecules can be involved in various types of noncovalent contacts [14]. Aromatic molecules can form stacking interactions with another aromatic molecule, even at very large 
horizontal displacements [15]. If interacting with water, aromatic molecules can be involved in three types of interactions: water-aromatic parallel interactions, $\mathrm{OH} / \pi$ and $\mathrm{C}-\mathrm{H} / \mathrm{O}$ interactions [16].

Even though results of previous studies indicated that geometry of $\mathrm{C}-\mathrm{H} / \mathrm{O}$ contacts of non-aromatic $\mathrm{C}-\mathrm{H}$ groups are typically linear, our studies of $\mathrm{C}-\mathrm{H} / \mathrm{O}$ contacts involving aromatic $\mathrm{C}-\mathrm{H}$ groups showed that these contacts do not have the tendency for the linear arrangement [17-21]. The statistical survey of the crystallographic data retrieved from the Cambridge Structural Database (CSD) revealed that different aromatic molecules able to donate hydrogen atom from $\mathrm{C}-\mathrm{H}$ fragments (benzene, pyridine, nucleic bases and aromatic amino acids) do not show tendency to form linear contacts. It was also revealed that the non-linearity of these contacts is consequence of additional interactions with the substituents on carbon atoms neighbouring to the interacting $\mathrm{C}-\mathrm{H}$ fragment. These results were verified by $a b$ initio calculations which indicated that in $\mathrm{C}-\mathrm{H} / \mathrm{O}$ interactions linear arrangement is not energetically favoured if $\mathrm{C}-\mathrm{H}$ donor is part of aromatic system. Results of $a b$ initio calculations showed energy of bifurcated $\mathrm{C}-\mathrm{H} / \mathrm{O}$ interaction in benzene/water complex is $-1.38 \mathrm{kcal} / \mathrm{mol}$, whilst the energy of linear $\mathrm{C}-\mathrm{H} / \mathrm{O}$ hydrogen bond between benzene and water is $-1.28 \mathrm{kcal} / \mathrm{mol}$ [17]. Calculations showed similar results for heterocyclic aromatic molecules: the interaction energies for the bifurcated $\mathrm{C}-\mathrm{H} / \mathrm{O}$ contacts in pyridine/water and nucleic bases/water complexes are stronger in comparison to the linear interactions $[18,20]$. Also, calculated interaction energies in water/benzene/water complexes revealed that when two water molecules form $\mathrm{C}-\mathrm{H} / \mathrm{O}$ contacts with benzene, these interactions weaken each other [19].

Here is presented a systematic study of energies and geometries of $\mathrm{C}-\mathrm{H} / \mathrm{O}$ interactions involving polycyclic aromatic hydrocarbons (PAHs) as hydrogen donors. The results are based on the quantum chemical calculations on model systems containing water and polycyclic aromatic hydrocarbon (PAH) molecules with a different number of condensed aromatic rings. Although interactions between the water molecule and aromatic rings of PAHs or graphene structures were being subject of numerous computational studies [2225], there is no computational study of $\mathrm{C}-\mathrm{H} / \mathrm{O}$ interactions involving $\mathrm{PAH}$ molecules as $\mathrm{C}-\mathrm{H}$ donors. To the best of our knowledge, this is the first study of $\mathrm{C}-\mathrm{H} / \mathrm{O}$ contacts of polycyclic aromatic hydrocarbons pointing out the importance of size of aromatic system for the energy of $\mathrm{C}-\mathrm{H} / \mathrm{O}$ interactions.

\section{Computational details}

$A b$ initio study was conducted on three model systems: naphthalene/water, anthracene/water and tetracene/water. For every $\mathrm{C}-\mathrm{H}$ fragment of aromatic $\mathrm{C}-\mathrm{H}$ donors, two different geometrical arrangements of $\mathrm{C}-\mathrm{H} / \mathrm{O}$ interactions were considered: linear and bifurcated. In the bifurcated geometries, the oxygen atoms were in between two neighbouring hydrogen atoms attached to the aromatic ring. The geometric parameters used to define $\mathrm{C}-\mathrm{H} / \mathrm{O}$ contacts are given in Fig. S1. The distance between interacting $\mathrm{C}-\mathrm{H}$ 
fragment of PAH and oxygen atom is marked with d. Angle $\alpha$ is the angle between atoms $\mathrm{C}$, $\mathrm{H}$ and $\mathrm{O}$. In all model systems water molecule was in perpendicular orientation to the aromatic ring (Fig.S1), since our previous results on $\mathrm{C}-\mathrm{H} / \mathrm{O}$ interactions in benzene/water system showed that in this orientation interactions are more stable [17].

The geometries of all molecules used in this study (naphthalene, anthracene, tetracene and water) were optimized. The optimized geometries were used for the singlepoint energy calculations of $\mathrm{C}-\mathrm{H} / \mathrm{O}$ interactions. To obtain the geometries with minimal energies, distances between PAHs and water were systematically varied from 2 to $3 \AA$. In all calculations cc-pVTZ basis set and the Møller-Plesset second-order perturbation method (MP2) were applied [26]. It has been shown that results obtained using this level of theory are in excellent agreement with the interaction energies calculated at CCSD(T)/CBS level which is considered to be "golden standard" in quantum chemistry (in case of benzenewater $\mathrm{C}-\mathrm{H} / \mathrm{O}$ interactions difference between interaction energies obtained using these two level of theories was approximately 2\%). [17] The counterpoise approach was used to correct interaction energies for the basis set superposition error (BSSE). [27]

Geometry optimizations, single point energy calculations and wavefunction file calculations were done using Gaussian 09 program package [28]. Obtained wavefunction files were used to calculate and visualize electrostatic potential maps with the Wavefunction Analysis Program (WFA-SAS) [29]. HOMA indexes were calculated from wavefunction files using Multiwfn software [30].

\section{Results and discussion}

To reveal the influence of size of aromatic system on the strength of $\mathrm{C}-\mathrm{H} / \mathrm{O}$ interactions we estimated the interaction energies in linear and bifurcated $\mathrm{C}-\mathrm{H} / \mathrm{O}$ interactions by performing quantum chemical calculations on the following model systems: naphthalene/water, anthracene/water and tetracene/water. The calculated interaction energies at MP2/cc-pVTZ level are given in Table 1. Results for energies and geometries of $\mathrm{C}-\mathrm{H} / \mathrm{O}$ interactions between benzene and water molecules were taken from our previous work [17] and compared with energies of $\mathrm{C}-\mathrm{H} / \mathrm{O}$ interactions between aromatic molecules and water calculated in this work.

Results showed that in all cases bifurcated $\mathrm{C}-\mathrm{H} / \mathrm{O}$ interactions are stronger than linear. This agrees with our previous results for benzene/water, pyridine/water and nucleic bases/water systems [17-20]. It should be pointed out that bifurcated interactions involve two hydrogen atoms instead of one (if interaction energies of bifurcated interactions are divided by two, linear interaction became stronger than bifurcated interactions). Hovewer, bifurcated $\mathrm{C}-\mathrm{H} / \mathrm{O}$ interactions involving $\mathrm{PAHs}$ as $\mathrm{C}-\mathrm{H}$ donors are recognized in crystal structures (Fig. S3). 
Results also showed that an additional aromatic ring in polycyclic aromatic hydrocarbon molecules strengthens both bifurcated and linear $\mathrm{C}-\mathrm{H} / \mathrm{O}$ contacts between polycyclic aromatic molecules and water. The strongest bifurcated $\mathrm{C}-\mathrm{H} / \mathrm{O}$ interaction involves the largest aromatic system, tetracene, and water molecule ( $\mathrm{C} 5-\mathrm{H} / \mathrm{C} 6-\mathrm{H}$ interaction), $-2.22 \mathrm{kcal} / \mathrm{mol}$. It is followed by anthracene/water $(\mathrm{C} 1-\mathrm{H}, \mathrm{C} 9-\mathrm{H})$ interaction ($2.10 \mathrm{kcal} / \mathrm{mol})$, then naphthalene/water $(\mathrm{C} 1-\mathrm{H}, \mathrm{C} 8-\mathrm{H})$ interaction $(-1.92 \mathrm{kcal} / \mathrm{mol})$, while the weakest bifurcated $\mathrm{C}-\mathrm{H} / \mathrm{O}$ interaction is interaction of the smallest aromatic molecule, benzene $(-1.38 \mathrm{kcal} / \mathrm{mol})$ (Table 1$)$.

Table 1. Calculated interaction energies and distances of $\mathrm{C}-\mathrm{H} / \mathrm{O}$ interactions in benzene/water, naphthalene/water, anthracene/water and tetracene/water complexes (Fig. 2).

\begin{tabular}{|c|c|c|c|}
\hline Model system & Geometry & C-H...O Distance (Å) & $\Delta \mathrm{E}(\mathrm{kcal} / \mathrm{mol})$ \\
\hline \multirow[t]{2}{*}{ Benzene-water $^{[a]}$} & Linear $\mathrm{C} 1 \mathrm{H} \ldots \mathrm{O}$ & 2.50 & -1.28 \\
\hline & Bifurcated $(\mathrm{C} 1-\mathrm{H} \ldots \mathrm{O}, \mathrm{C} 2-\mathrm{H} \ldots \mathrm{.}$ ) & 2.80 & -1.38 \\
\hline \multirow[t]{5}{*}{ Naphthalene-water } & Linear $\mathrm{C} 1-\mathrm{H} . . . \mathrm{O}$ & 2.50 & -1.60 \\
\hline & Linear $\mathrm{C} 2-\mathrm{H} \ldots \mathrm{O}$ & 2.50 & -1.38 \\
\hline & Bifurcated (C1-H...O, C2-H...O) & 2.50 & -1.50 \\
\hline & Bifurcated $(\mathrm{C} 2-\mathrm{H} \ldots \mathrm{O}, \mathrm{C} 3-\mathrm{H} \ldots \mathrm{O})$ & 2.60 & -1.41 \\
\hline & Bifurcated $(\mathrm{C} 1-\mathrm{H} \ldots \mathrm{O}, \mathrm{C} 8-\mathrm{H} \ldots \mathrm{O})$ & 2.60 & -1.92 \\
\hline \multirow[t]{6}{*}{ Anthracene-water } & Linear $\mathrm{C} 1-\mathrm{H} . . . \mathrm{O}$ & 2.50 & -1.70 \\
\hline & Linear $\mathrm{C} 2-\mathrm{H} \ldots \mathrm{O}$ & 2.50 & -1.42 \\
\hline & Linear $\mathrm{C} 9-\mathrm{H} . . . \mathrm{O}$ & 3.00 & -1.81 \\
\hline & Bifurcated $(\mathrm{C} 1-\mathrm{H} \ldots \mathrm{O}, \mathrm{C} 2-\mathrm{H} \ldots \mathrm{O})$ & 2.80 & -1.56 \\
\hline & Bifurcated $(\mathrm{C} 2-\mathrm{H} \ldots \mathrm{O}, \mathrm{C} 3-\mathrm{H} \ldots \mathrm{O})$ & 2.80 & -1.59 \\
\hline & Bifurcated $(\mathrm{C} 1-\mathrm{H} \ldots \mathrm{O}, \mathrm{C} 9-\mathrm{H} \ldots \mathrm{O})$ & 2.60 & -2.10 \\
\hline \multirow[t]{7}{*}{ Tetracene-water } & Linear $\mathrm{C} 1-\mathrm{H} . . . \mathrm{O}$ & 2.50 & -1.71 \\
\hline & Linear $\mathrm{C} 2-\mathrm{H} \ldots \mathrm{O}$ & 2.50 & -1.46 \\
\hline & Linear $\mathrm{C} 5-\mathrm{H} \ldots \mathrm{O}$ & 2.50 & -1.99 \\
\hline & Bifurcated $(\mathrm{C} 1-\mathrm{H} \ldots \mathrm{O}, \mathrm{C} 2-\mathrm{H} \ldots \mathrm{O})$ & 2.80 & -1.57 \\
\hline & Bifurcated $(\mathrm{C} 2-\mathrm{H} \ldots \mathrm{O}, \mathrm{C} 3-\mathrm{H} \ldots \mathrm{O})$ & 2.80 & -1.64 \\
\hline & Bifurcated $(\mathrm{C} 4-\mathrm{H} \ldots \mathrm{O}, \mathrm{C} 5-\mathrm{H} \ldots \mathrm{O})$ & 2.60 & -2.12 \\
\hline & Bifurcated $(\mathrm{C} 5-\mathrm{H} \ldots \mathrm{O}, \mathrm{C} 6-\mathrm{H} \ldots \mathrm{O})$ & 2.60 & -2.22 \\
\hline
\end{tabular}

${ }^{[a]}$ Data taken from ref. 17.

Trends are similar in case of linear $\mathrm{C}-\mathrm{H} / \mathrm{O}$ interactions: the strongest linear $\mathrm{C}-\mathrm{H} / \mathrm{O}$ interaction is $\mathrm{C} 5-\mathrm{H} / \mathrm{O}$ interaction between tetracene and water molecule $(-1.99 \mathrm{kcal} / \mathrm{mol})$, then $\mathrm{C} 9-\mathrm{H}$ interaction between anthracene and water molecule $(-1.81 \mathrm{kcal} / \mathrm{mol})$, then $\mathrm{C} 1-$ $\mathrm{H} / \mathrm{O}$ interaction between naphthalene and water molecule $(-1.60 \mathrm{kcal} / \mathrm{mol})$, while the weakest linear interaction is $\mathrm{C}-\mathrm{H} / \mathrm{O}$ interaction between benzene and water molecule $(-1.28$ $\mathrm{kcal} / \mathrm{mol})$.

It is also interesting that hydrogen atoms from inner condensed aromatic rings of anthracene $(\mathrm{C} 9-\mathrm{H})$ and tetracene $(\mathrm{C} 5-\mathrm{H}, \mathrm{C} 6-\mathrm{H})$ form significantly stronger linear interactions than hydrogen atoms from outer aromatic rings. Bifurcated interactions of hydrogen atoms attached to inner rings are also stronger than bifurcated interactions involving hydrogen atoms attached to outer condensed rings. It is most obvious in the case of tetracene, where 
the strongest bifurcated interaction involves two hydrogen atoms attached to inner rings $(\mathrm{C} 5-\mathrm{H}, \mathrm{C} 6-\mathrm{H}),-2.22 \mathrm{kcal} / \mathrm{mol}$. Slightly weaker are bifurcated interactions involving one hydrogen atom from inner and one from outer ring $(\mathrm{C} 4-\mathrm{H}, \mathrm{C} 5-\mathrm{H}),-2.12 \mathrm{kcal} / \mathrm{mol}$, while the weakest are bifurcated interactions involving two hydrogen atoms attached to outer ring (C4-H, C5-H), - $1.57 \mathrm{kcal} / \mathrm{mol}$.

Analysis of results showed that influence of number of aromatic rings in polycyclic aromatic hydrocarbons on the strength of $\mathrm{C}-\mathrm{H} / \mathrm{O}$ interaction is so strong that linear $\mathrm{C}-\mathrm{H} / \mathrm{O}$ interactions of polycyclic aromatic hydrocarbons with larger number of aromatic rings in some cases are stronger than bifurcated $\mathrm{C}-\mathrm{H} / \mathrm{O}$ interactions of polycyclic aromatic hydrocarbons with smaller number of aromatic rings. For example, linear $\mathrm{C} 5 \mathrm{-H}$ interaction in tetracene/water system $(-1.99 \mathrm{kcal} / \mathrm{mol})$ is stronger than bifurcated $(\mathrm{C} 1-\mathrm{H}, \mathrm{C} 2-\mathrm{H})$ and $(\mathrm{C} 2-\mathrm{H}, \mathrm{C} 3-\mathrm{H})$ interactions in anthracene/water systems $(-1.59 \mathrm{kcal} / \mathrm{mol}$ and $-1.56 \mathrm{kcal} / \mathrm{mol}$, respectivelly). It is interesting that bifurcated $(\mathrm{C} 5-\mathrm{H}, \mathrm{C6}-\mathrm{H})$ contacts in tetracene/water system $(-2.22 \mathrm{kcal} / \mathrm{mol})$ is slightly stronger than bifurcated $\mathrm{C}-\mathrm{H} / \mathrm{O}$ contact between meta and para $\mathrm{C}-\mathrm{H}$ groups of pyridine in pyridine/water $\mathrm{C}-\mathrm{H} / \mathrm{O}$ interactions $(-2.21 \mathrm{kcal} / \mathrm{mol})$ [18]. To understand the results on energies of $\mathrm{C}-\mathrm{H} / \mathrm{O}$ hydrogen bonds, electrostatic potential maps for all studied aromatic molecules were calculated (Fig. 1).

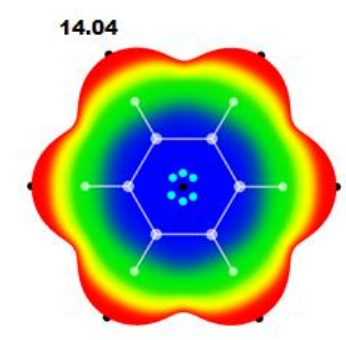

a)

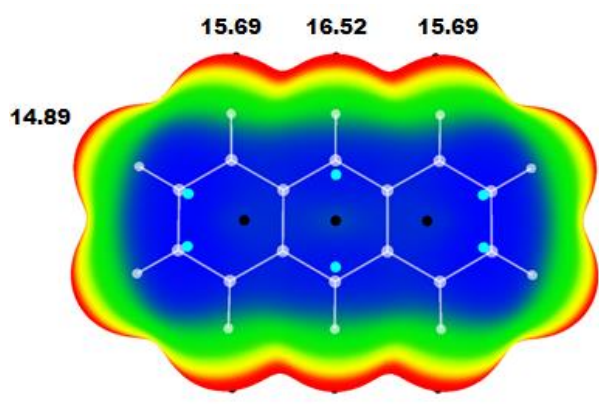

c)

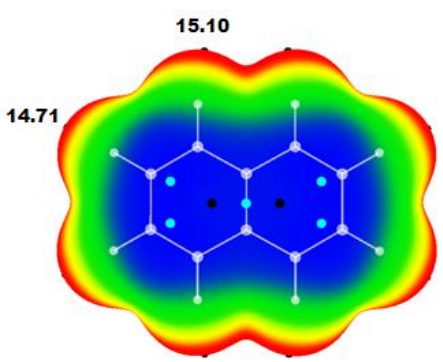

b)

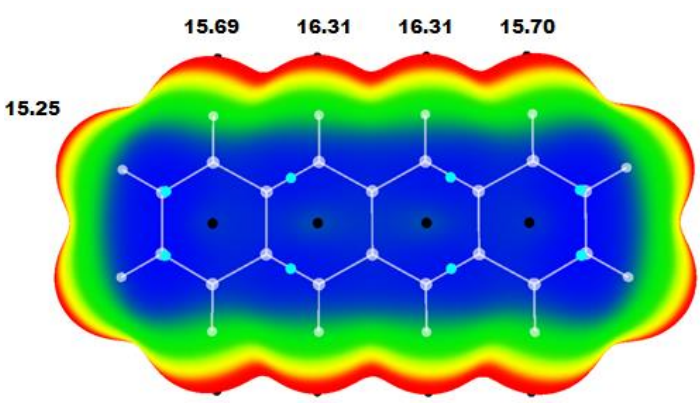

d)

Figure 1. Electrostatic potential maps of: a) benzene b) naphthalene $c$ ) anthracene and d) tetracene displayed on the 0.001 au surface (MP2/cc-PVTZ level). Color ranges (in kcal/mol): red, > 6.40; yellow, 0.00 - 6.40; green, -8.91 - 0.00; blue, <-8.91. In all polycyclic aromatic hydrocarbon molecules atoms from $\mathrm{C}-\mathrm{H}$ groups have positive electrostatic potentials.

Positive parts of electrostatic potential map surface are colored in red and negative parts are colored in blue. Blue and black points on the electrostatic potential maps are 
critical points. These represent the locations of minimal or maximal values of electrostatic potential. Results of calculated electrostatic potentials are in good agreement with the calculated energies of $\mathrm{C}-\mathrm{H} / \mathrm{O}$ interactions. The positive areas of electrostatic potential are located on hydrogen atoms, with the most positive areas are around hydrogen atoms in the middle of the molecules $(\mathrm{C} 1-\mathrm{H}$ in naphthalene, $\mathrm{C}-\mathrm{H}$ in anthracene and $\mathrm{C} 5-\mathrm{H}$ and $\mathrm{C} 6-\mathrm{H}$ in tetracene).

The strongest bifurcated $\mathrm{C}-\mathrm{H} / \mathrm{O}$ interaction is formed between oxygen from water molecule and $\mathrm{C} 5-\mathrm{H}$ and $\mathrm{C} 6-\mathrm{H}$ fragments of tetracene that has the most positive potential. On the other hand, electrostatic potential map shows that region around hydrogen atom of benzene is the least positive, which is in agreement with the interaction energies calculations showing that $\mathrm{C}-\mathrm{H} / \mathrm{O}$ contacts of benzene are the weakest of all studied aromatic molecules.

Harmonic Oscillator Model of Aromaticity (HOMA) indexes were calculated for all aromatic rings in studied PAH structures (Table S1.). Results showed that HOMA values for outer rings of anthracene (ring I, 0.93) and tetracene (ring I, 0.69) are larger than HOMA values for inner rings of anthracene (ring II, 0.89) and tetracene (ring II, 0.67). Since larger values of HOMA indexes are related to lower polarizability, these results are in agreement with results of $a b$ initio calculations which show that hydrogen atoms attached to inner rings form stronger $\mathrm{C}-\mathrm{H} / \mathrm{O}$ interactions than hydrogen atoms attached to outer rings.

For the most stable PAH/water systems geometries were optimized at MP2/cc-PVTZ level and resulting geometries are shown in Fig. $\mathbf{2}$.

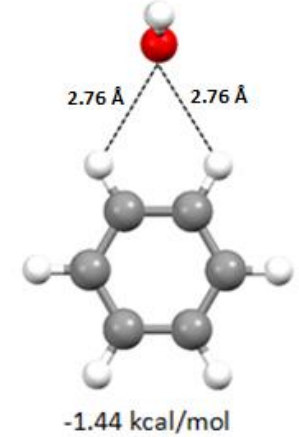

(a)

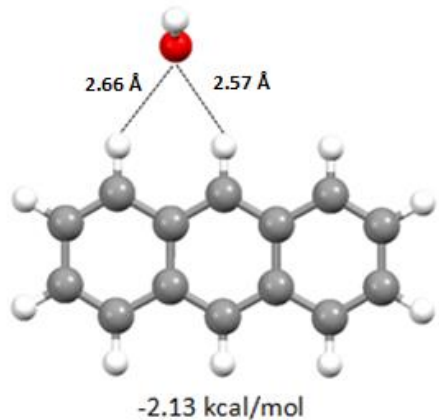

(c)

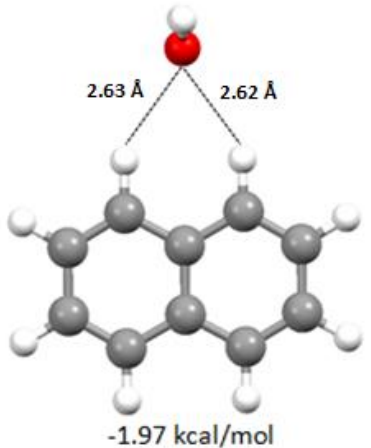

(b)

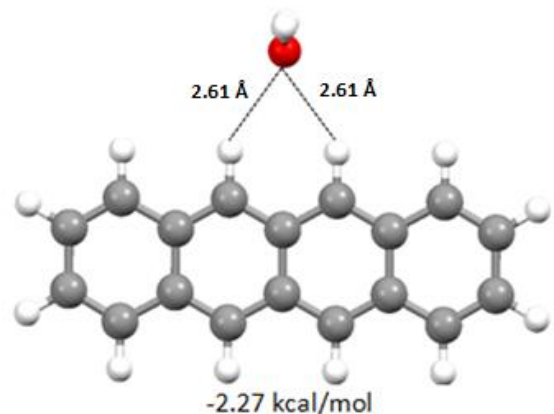

(d)

Figure 2. Optimized geometries of most stable a) benzene/water b) naphthalene/water, c) anthracene/water and d) tetracene/water structures. 
Interaction energies in the optimized geometries are somewhat stronger compared with data in Table $1 ;-1.97 \mathrm{kcal} / \mathrm{mol}$ for naphthalene/water, $-2.13 \mathrm{kcal} / \mathrm{mol}$ for anthracene/water and $-2.27 \mathrm{kcal} / \mathrm{mol}$ for tetracene/water complex. Stronger $\mathrm{C}-\mathrm{H} / \mathrm{O}$ interactions in these model systems are related to shorter hydrogen-oxygen distances. In optimized anthracene/water complex $\mathrm{C}-\mathrm{H} 1 / \mathrm{O}$ interaction (2.66 $\AA$ ) is significantly longer than $\mathrm{C}-\mathrm{H} 9 / \mathrm{O}$ interactions ( $2.57 \AA$ ) $)$. A stronger tendency of $\mathrm{H} 9$ atom to attract oxygen atom agrees with electrostatic potential maps; electrostatic potential on $\mathrm{H} 9$ atom is $16.52 \mathrm{kcal} / \mathrm{mol}$ and on $\mathrm{H} 1$ atom is $15.96 \mathrm{kcal} / \mathrm{mol}$.

\section{Conclusion}

Results presented in this study show that an additional aromatic ring in structure of polycyclic aromatic hydrocarbons significantly strengthens $\mathrm{C}-\mathrm{H} / \mathrm{O}$ interactions in which these molecules act as $\mathrm{C}-\mathrm{H}$ donors. Both linear and bifurcated $\mathrm{C}-\mathrm{H} / \mathrm{O}$ interactions between $\mathrm{PAHs}$ and water are significantly stronger for PAH molecules with larger number of aromatic rings. Interaction energies in optimized structures of the most stable tetracene/water complex is $-2.27 \mathrm{kcal} / \mathrm{mol}$, anthracene/water is $-2.13 \mathrm{kcal} / \mathrm{mol}$ and naphthalene/water is $-1.97 \mathrm{kcal} / \mathrm{mol}$. $\mathrm{C}-\mathrm{H} / \mathrm{O}$ interactions in tetracene/water system are stronger than $\mathrm{C}-\mathrm{H} / \mathrm{O}$ interactions in benzene/water $(-1.44 \mathrm{kcal} / \mathrm{mol})$ and even pyridine/water complexes $(-2.21$ $\mathrm{kcal} / \mathrm{mol})[18]$.

Analysis of $a b$ initio calculations results also reveal that in case of $\mathrm{C}-\mathrm{H} / \mathrm{O}$ interactions between PAHs and water molecules, bifurcated hydrogen bonds are energetically more stable than linear hydrogen bonds. This result agrees with previously calculated trends for benzene/water, pyridine/water, nucleic bases/water and aromatic amino acids/water systems [17-21].

Results of electrostatic potential maps calculations for PAH molecules are consistent with the calculated $\mathrm{C}-\mathrm{H} / \mathrm{O}$ interaction energies. Analysis of electrostatic potential maps show that most positive electrostatic potential is in the regions of hydrogen atoms involved in the strongest $\mathrm{C}-\mathrm{H} / \mathrm{O}$ contacts.

Results presented here may be important in future studies of $\mathrm{C}-\mathrm{H} / \mathrm{O}$ hydrogen bonds in crystal structures, mechanism of catalysis and in designing new materials with higher preference for hydrogen bonding. Knowledge that additional aromatic rings strengthen $\mathrm{C}-\mathrm{H} / \mathrm{O}$ contacts involving $\mathrm{PAH}$ molecules could be used in future studies to explain arrangements of atoms and crystal packing in crystal structures.

\section{Acknowledgement}

This work was supported by the Serbian Ministry of Education, Science and Technological Development (grant 172065). Author would like to thank Prof. Snežana Zarić from Department of Chemistry - University of Belgrade for help. 


\section{References:}

[1] T. Steiner, Angew. Chem. Int. Ed. Engl. 2002, 41, 48-76.

[2] T. Steiner, G. R. Desiraju, Chem. Commun. 1998, 891-892.

[3] S. Scheiner, Phys. Chem. Chem. Phys. 2011, 13, 13860-13872.

[4] C. E. Cannizzaro, K. N. Houk, J. Am. Chem. Soc. 2002, 124, 7163- 7169.

[5] M. C. Wahl, M. Sundaralingam, Trends in Biochemical Sciences, 1997, 22, 97-102.

[6] G. R. Desiraju, T. Steiner, The weak hydrogen bond in structural chemistry and biology. New York: Oxford University press, 1999.

[7] A. Nangia, Cryst. Eng., 2001, 4, 49-59.

[8] a) N. A. Wasio, R. C. Quardokus, R. P. Forrest, C. S. Lent, S. A. Corcelli, J. A. Christie, K. W. Henderson, S. A. Kandel, Nature 2014, 507, 86-89; b) J. Kim, H. Xiao, J. B. Bonanno, C. Kalyanaraman, S. Brown, X. Tang, N. F. Al-Obaidi, Y. Patskovsky, P. C. Babbitt, M. P. Jacobson, Y. S. Lee, S. C. Almo, Nature 2013, 498, 123-126; c) Q. Li, W. Nannan, Z. Yu, Comp. Theor. Chem, 2007, 847, 68-74.

[9] S. Scheiner, Crystals 2015, 5 (3), 327-345; b) G. R Desiraju, Acc. Chem. Res, 1996, 29, 441-449.

[10] Lavanya, S. Ramaiah, A. Anbarasu, J Biol Phys, 2013, 39, 649-663.

[11] S. Tsuzuki, T. Uchimaru, M. Mikami, Theor Chem Acc, 2012, 131, 1192, 1-8.

[12] a) Z. S. Derewenda, L. Lee, U. Derewenda, J. Mol. Biol. 1995, 252, 248-262; b) G. F. Fabiola, S. Krishnaswamy, V. Nagarajan, V. Pattabhi, Acta Crystallogr.,Sect. D: Biol. Crystallogr. 1997, 53, 316320.

[13] a) M. S. Weiss, Trends Biochem. Sci. 2001, 26, 521-523; b) R. K. Castellano, Curr. Org. Chem. 2004, 8, 845-865; (c) S. Scheiner, T. Kar, J. Phys. Chem. B, 2005, 109, 3681-3689; d) P. Chakrabarti, R. Bhattacharyya, Prog. Biophys. Mol. Biol. 2007, 95, 83-137; e) S. Scheiner, J. Phys. Chem. B, 2006, 110, 18670-18679; f) H. Park, J. Yoon, C. Seok, J. Phys. Chem. B, 2008, 112(3), 1041-1048; g) K. Manikandan, S. Ramakumar, Proteins: Struct., Funct., Bioinf. 2004, 56, 768-781.

[14] a) L. M. Salonen, M. Ellermann, F. Diederich Angew. Chem. Int. Ed. 2011, 50, 4808-4842; b) C. A. Hunter, K. R. Lawson, J. Perkins, C. J. Urch, Chem. Soc. Perkin Trans. 2001, 2 651-669.

[15] D. B. Ninković, G. V. Janjić, D. Ž. Veljković, D. N. Sredojević, S. D. Zarić, ChemPhysChem, 2011, $12,3511-3514$.

[16] a) E. C. Lee, D. Kim, P. Jurečka, P. Tarakeshwar, P. Hobza, K. S. Kim, J. Phys. Chem. A, 2007, 111, 3446; b) M. P. Mitoraj, G. V. Janjić, V. B. Medaković, D. Ž. Veljković, A. Michalak, S. D. Zarić, M. K. Milčić, J. Comput. Chem. 2015, 36, 171-180; c) G. V. Janjić, D. Ž. Veljković, S. D. Zarić, Cryst. Growth Des. 2011, 11, 2680-2683; d) L. M. Salonen, M. Ellermann, F. Diederich, Angew. Chem., Int. Ed. 2011, 50, 4808-4842; e) S. E. Wheeler, J. W. G. Bloom, J. Phys. Chem. A, 2014, 118 (32), 6133-6147.

[17] D. Ž. Veljković, G. V. Janjić, S. D. Zarić, CrystEngComm 2011, 13, 5005-5010. 
[18] J. L. Dragelj, G. V. Janjić, D. Ž. Veljković, D. Z. Snežana, CrystEngComm 2013, 15, 10481-10489.

[19] D. P Malenov, G. V. Janjić, D. Ž. Veljković, S. D. Zarić, Comput. Theor. Chem. 2013, 1018, 59-65.

[20] D. Ž. Veljković, V. B. Medaković, J. M. Andrić, S. D. Zarić, CrystEngComm 2014, 16, 1008910096.

[21] J. Lj. Dragelj, I. M. Stanković, D. M. Božinovski, T. Meyer, D. Ž. Veljković, V. B. Medaković, E.-W. Knapp, S. D. Zarić, Cryst. Growth Des. 2016, 16, 1948-1957.

[22] M. Rubeš, P. Nachtigall, J. Vondrášek, O. Bludský, J. Phys. Chem. C 2009, 113, 8412-8419.

[23] J. Kysilka, M. Rubeš, L. Grajciar, P. Nachtigall, O. Bludský, J. Phys. Chem. A 2011, 115, 1138711393.

[24] M. Prakash, K. G. Samy, V. Subramanian, J. Phys. Chem. A 2009, 113, 13845-13852.

[25] R. R. Q. Freitas, R. Rivelino, F. de B. Mota, C. M. C. de Castilho, J. Phys. Chem. A 2011, 115, 12348-12356.

[26] a) C. Møller, M. S. Plesset, Phys. Rev. 1934, 46, 618-622; b) M. Head-Gordon, J. A. Pople, M. J. Frish, Chem. Phys. Lett. 1988, 153, 503-506.

[27] S. B. Boys, F. Bernardi, Mol. Phys. 1970, 19, 553-566.

[28] M. J. Frisch, G. W. Trucks, H. B. Schlegel, G. E. Scuseria, M. A. Robb, J. R. Cheeseman, G. Scalmani, V. Barone, B. Mennucci, G. A. Petersson, H. Nakatsuji, M. Caricato, X. Li, H. P. Hratchian, A. F. Izmaylov, J. Bloino, G. Zheng, J. L. Sonnenberg, M. Hada, M. Ehara, K. Toyota, R. Fukuda, J. Hasegawa, M. Ishida, T. Nakajima, Y. Honda, O. Kitao, H. Nakai, T. Vreven, J. A. Montgomery, Jr., J. E. Peralta, F. Ogliaro, M. Bearpark, J. J. Heyd, E. Brothers, K. N. Kudin, V. N. Staroverov, R. Kobayashi, J. Normand, K. Raghavachari, A. Rendell, J. C. Burant, S. S. Iyengar, J. Tomasi, M. Cossi, N. Rega, J. M. Millam, M. Klene, J. E. Knox, J. B. Cross, V. Bakken, C. Adamo, J. Jaramillo, R. Gomperts, R. E. Stratmann, O. Yazyev, A. J. Austin, R. Cammi, C. Pomelli, J. W. Ochterski, R. L. Martin, K. Morokuma, V. G. Zakrzewski, G. A. Voth, P. Salvador, J. J. Dannenberg, S. Dapprich, A. D. Daniels, Ö. Farkas, J. B. Foresman, J. V. Ortiz, J. Cioslowski and D. J. Fox, Gaussian, Inc., Wallingford CT, 2009.

[29] a) F. A. Bulat, A. Toro-Labbe, WFA: A suite of programs to analyse wavefunctions, unpublished; b) F. A. Bulat, A. Toro-Labbé, T. Brinck, J. S. Murray, P. Politzer, J. Mol. Model. 2010, 16, 1679-1691.

[30] T. Lu, F. Chen, J. Comp. Chem. 2012, 33, 580-592. 